\title{
III-V material solar cells for space application
}

\author{
T.V. Torchynska, G.P. Polupan \\ National Polytechnic Institute Mexico, U.P.A.L.M., Ed.9, 07320, Mexico D.F. \\ Institute of Semiconductor Physics, NAS of Ukraine, 45 prospect Nauky, 03028 Kyiv, Ukraine \\ e-mail: ttorch@esfm.ipn.mx
}

\begin{abstract}
The present paper is a review of current situation in space solar cell engineering. The comparison of the $\mathrm{Si}$ and III-V solar cell performances, as well as their parameter variation with temperature rise, radiation treatments and improving design were analyzed. The modern directions of the space solar cell development and international space projects, applied new types of solar cells, were discussed as well.
\end{abstract}

Keywords: solar cell, III-V compounds, semiconductor, conversion efficiency

Paper received 15.10.01; revised manuscript received 10.01.02; accepted for publication 05.03.02.

\section{Introduction}

Starting from the 1953 year, when the semiconductor solar cells (SC) were invented, SCs were mainly applied in space satellite energy systems. Only after international oil crisis in 1973, the decision of exploring the solar cell technology potential for terrestrial applications appeared. Until this period the photovoltaic $(\mathrm{PV})$ technology was extensively investigated, developed and is still in progress now [1,2]. Up to 1990, the solar cells were mainly created using single crystal, polycrystalline and amorphous $\mathrm{Si}$. The latter was caused by the comparatively high efficiency of these solar cells $(\eta=13-16 \%)$ and relatively cheap technology. Prices of GaAs SC, for example, were around ten times higher than those of Si SC. Only beginning from 1990 when the GaAs SC technology moved into volume production the prices of GaAs SC dropped to five times of the Si SC ones. Sharp rise of GaAs SC volume production was connected with revolution in the satellite industry [3]. The latter stemmed from the improvements in III-V solar cell design, coupled with demands for satellites to have higher on-board power.

In the presented review, the comparison of $\mathrm{Si}, \mathrm{GaAs}$,
AlGaAs, InGaP and InP SC parameters, their variations with temperature rise, radiation treatment and improving design have been analyzed. The modern international space projects, applied new types of the SC, are discussed as well.

\section{Semiconductor solar cells}

Photons with energy above the semiconductor band gaps are absorbed in SC and generate electron - hole pairs. The excess minority carriers diffuse to the spacecharge layer, pass through the junction and create the photocurrent, voltage and output power on the load resistance. The excess photocarrier diffusion to $p-n$ junction is also accompanied with their loss due to the surface and bulk recombination.

The most important SC parameter is conversion efficiency $\eta$

$$
\eta=P_{m} / P_{i n}=F F . U_{o c} \cdot J_{s c} / P_{i n},
$$

where $P_{m}=I_{m} U_{m}$ is the maximum output power of SC, $P_{i n}$ - the integral solar incident power on front contact, $\mathrm{U}_{\mathrm{oc}}$ - the open circuit voltage, $J_{S c}$ - the short circuit current density, $F F$ - the fill factor of I-U characteristics. As a rule, 


\section{T. V. Torchynska et al.: III-V material solar cells for space application}

the $\mathrm{SC}$ efficiency is estimated at AMO or AM1 sun light levels. AMO corresponds to the integral power 1.35$1.40 \mathrm{~kW} / \mathrm{m}^{2}$ and is the characteristic of sun radiation level before sun light passes through the Earth atmosphere. AM1 is appropriated to the sun radiation level on the see level after the sunlight passed through the Earth atmosphere.

Single crystal silicon - is the most studied semiconductor material, as well as Si SCs based on the single crystal p-n homojunction are the simplest photoelectric devices. These Si SCs working under nonconcentrated solar radiation with efficiency $\eta=13-16 \%$ had the most spread application in space solar energy devices. Si SCs based on microcrystalline and amorphous Si are very attractive for terrestrial applications due to their chipper price. However, the low value of their efficiency did not give a reason to expect their spread application in space or for concentrated sun light conversion.

Despite some shortages (brittle, high density) GaAs single crystal has essential advantages in comparison with silicon. GaAs single crystal has s a bigger band gap $(1.40 \mathrm{eV})$ and, as a result, cannot absorb the sun light with wavelengths $>0.9 \mu \mathrm{m}$. However, the same circumstance is the reason of the essentially low reverse excess saturation current, $\mathrm{J}_{\text {rev }}=10^{-9}-10^{-10} \mathrm{~A} / \mathrm{cm}^{2}$, in GaAs SC in comparison with Si SC, were $\mathrm{J}_{\mathrm{rev}}=10^{-6}-10^{-7} \mathrm{~A} / \mathrm{cm}^{2}$ (Table 1); as well as the higher value for open circuit voltage

Table 1. Parameters of optimized Si and GaAs solar cells.

\begin{tabular}{l|llll}
\hline $\begin{array}{c}\text { Solar cell } \\
\text { type }\end{array}$ & $\mathrm{n} / \mathrm{p} \mathrm{Si}$ & $\mathrm{p} / \mathrm{n} \mathrm{Si}$ & $\mathrm{n} / \mathrm{p}$ GaAs & $\mathrm{p} / \mathrm{n} \mathrm{GaAs}$ \\
$\begin{array}{l}\text { Parameter } \\
\mathrm{N}_{\mathrm{D}}\left(\mathrm{cm}^{-3}\right)\end{array}$ & $5 \times 10^{18}$ & $5 \times 10^{16}$ & $5 \times 10^{18}$ & $5 \times 10^{17}$ \\
\hline $\mathrm{N}_{\mathrm{A}}\left(\mathrm{cm}^{-3}\right)$ & $10^{17}$ & $5 \times 10^{17}$ & $5 \times 10^{17}$ & $5 \times 10^{18}$ \\
\hline $\mathrm{J}_{\mathrm{SC}}\left(\mathrm{mA} / \mathrm{cm}^{2}\right)$ & 36 & 35.9 & 26.5 & 28.1 \\
\hline $\mathrm{U}_{\mathrm{OC}}(\mathrm{V})$ & 0.64 & 0.62 & 1.05 & 1.09 \\
\hline$\eta_{\mathrm{a}}(\%)$ & 18.75 & 17.5 & 26.0 & 28.6 \\
\hline$\eta_{\mathrm{b}}(\%)$ & 22.5 & 22.0 & 29.0 & 30.2 \\
\hline $\mathrm{d} \eta / \mathrm{dT}$ \\
$(\% \mathrm{degr})$
\end{tabular}

and low coefficient for the efficiency change with temperature in GaAs SC [2,4].

Table 1 shows materials and solar cell parameters estimated for optimized Si and GaAs SCs [5,6]. As it can be seen, GaAs SCs are characterized by higher values of $\mathrm{U}_{\mathrm{oc}}$ and $\eta$ both at AM1.5 $\left(\eta_{\mathrm{a}}\right)$ and at the essential concentration $(C)$ of solar radiation $\left(\eta_{b}, C=80\right)$ in comparison with those of Si SCs [5-7].

It was discovered that $\mathrm{AlGaAs} / \mathrm{GaAs}$ interface is characterized by a small density of extended defects and recombination centers due to practically the same lattice parameters at epitaxial layer growth temperature. The

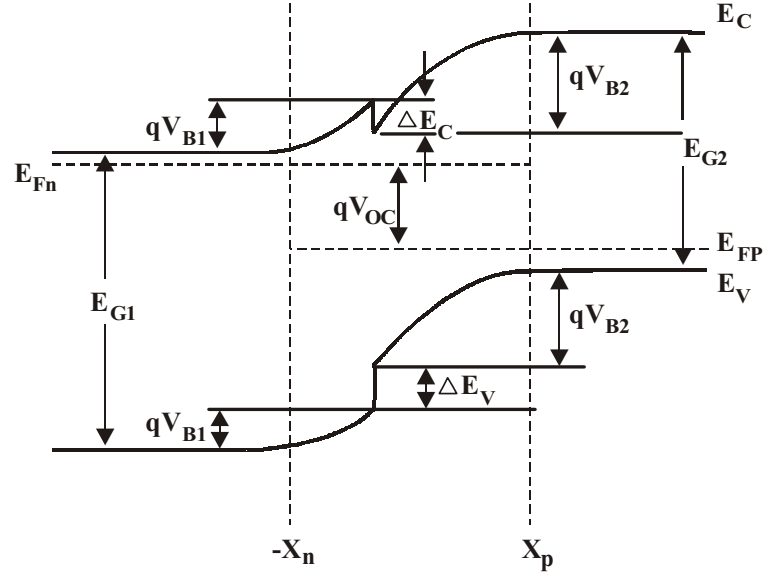

Fig. 1. The Energy band diagram of n-p AlGaAs / GaAs heterojunction.

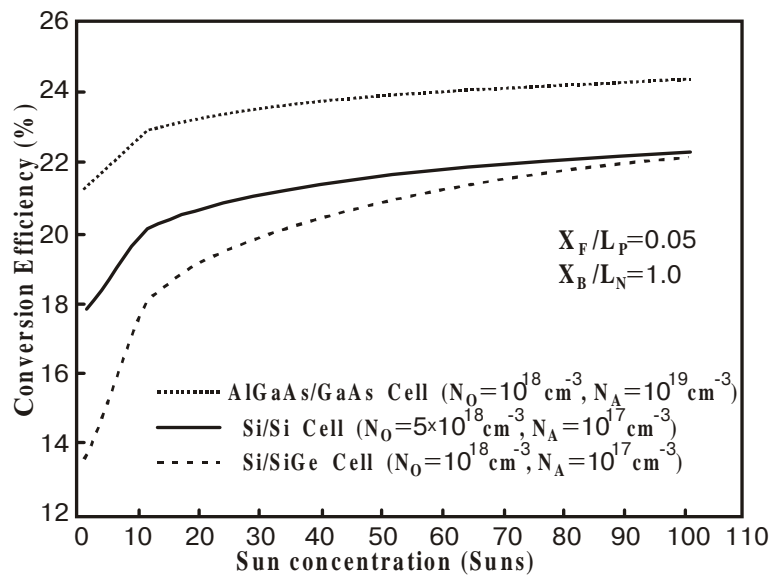

Fig. 2. Dependence of the conversion efficiency $\eta$ on the sun concentration.

latter has provided in solar cells based on AlGaAs / GaAs structures the low surface recombination velocity $(\mathrm{S})$ and two sides carriers collection with high efficiency $\eta=25-27 \%$. The most popular GaAs SC were created using p-AlGaAs - p-GaAs - n-GaAs heterostructures [7-23]. Solar energy conversion into electricity inside a $\mathrm{SC}$ is due to photovoltaic effect in the barrier layer. The typical energy band diagram of a solar cell with n-p AlGaAs/GaAs heterojunction is presented in the Fig. 1.

For solar concentrated applications the dependence of conversion efficiency of these SCs on sun concentration is illustrated in Fig. 2 [7]. The highest obtained conversion efficiencies are $21.0 \%, 17.8 \%$ and $12.5 \%$ at 1 sun concentration for $\mathrm{AlGaAs} / \mathrm{GaAs}, \mathrm{Si} / \mathrm{Si}$ and $\mathrm{Si} / \mathrm{SiGe}$ solar cells, respectively. The results presented in Fig. 2 show that maximum efficiencies of about $25 \%, 22.5 \%$ and $22.5 \%$ for $\mathrm{AlGaAs} / \mathrm{GaAs}, \mathrm{Si} / \mathrm{Si}$ and $\mathrm{Si} / \mathrm{SiGe}$ concentrator devices could be achieved without including the possible improvements connected with geometry optimization or surface passivation [14-23]. 


\section{T. V. Torchynska et al.: III-V material solar cells for space application}

Table 2. Comparison of different SC performances on temperature and radiation

\begin{tabular}{|c|c|c|c|c|c|c|c|}
\hline \multirow[t]{3}{*}{$\begin{array}{l}\text { Type } \\
\text { SC materials }\end{array}$} & \multirow[t]{3}{*}{$\begin{array}{l}\text { Efficiency } \\
(\%)\end{array}$} & \multicolumn{2}{|c|}{$\begin{array}{c}\text { Power, W } \\
\text { Un-Irradiated }\end{array}$} & \multicolumn{4}{|c|}{$\begin{array}{c}\text { Power, W } \\
1 \mathrm{MeV} \text { Electron Fluence }\end{array}$} \\
\hline & & & & \multicolumn{2}{|c|}{$3 \times 10^{14} \mathrm{e} / \mathrm{cm}^{2}$} & \multicolumn{2}{|c|}{$1 \times 10^{15} \mathrm{e} / \mathrm{cm}^{2}$} \\
\hline & & $28^{\circ} \mathrm{C}$ & $50^{\circ} \mathrm{C}$ & $28^{\circ} \mathrm{C}$ & $50^{\circ} \mathrm{C}$ & $28^{\circ} \mathrm{C}$ & $50^{\circ} \mathrm{C}$ \\
\hline Silicon & 14.8 & 170.9 & 149.5 & 129.0 & 112.2 & 113.0 & 98.8 \\
\hline $\mathrm{GaAs} / \mathrm{Ge}$ & 18.5 & 218.1 & 208.2 & 188.1 & 179.6 & 166.8 & 159.3 \\
\hline GaInP/GaAs/Ge & 21.5 & 253.5 & 242.8 & 223.0 & 211.9 & 192.7 & 183.0 \\
\hline
\end{tabular}

\section{Different aspects of solar cell improvement}

The main ways to improve solar cell efficiency include: the expansion of spectral photosensitivity range; the reduction of $p-n$ junction depth; the increases of the minority carriers diffusion length in the base layer and reduction of the reverse $\mathrm{p}-\mathrm{n}$ junction saturation current; the use of additional homojunction barriers and p-n junctions; the decrease of surface recombination velocity on photosensitive surface; the optimization of contacts and others [24-57].

The expansion of spectral photosensitivity range of p-AlGaAs - p-GaAs - n-GaAs SCs could be achieved by the application of $\mathrm{Al}_{\mathrm{x}} \mathrm{Ga}_{1-\mathrm{x}} \mathrm{As}$ compositions with larger value of band gap, or by using another semiconductor materials with wider band gaps as windows.

It is essential that $\mathrm{Al}_{\mathrm{x}} \mathrm{Ga}_{1-\mathrm{x}} \mathrm{As}$ band gap increasing with $\mathrm{x}$ parameter rise is not accompanied by the stimulation of surface recombination in photosensitive area. The latter is the consequence of the indirect band gap for $\mathrm{Al}_{\mathrm{x}} \mathrm{Ga}_{1-\mathrm{x}} \mathrm{As}$ solid solution with $\mathrm{x}>0.34$. The same goal can be achieved when applying a varied-zone structure as a wide gap solid solution layer $[19,20]$.

Creation of the isotype potential barrier in heterostructures is used for reverse saturation current reduction [21-23].

The development of single (SQW) and multi quantum well (MQW) technologies, as well as superlattice creation in $\mathrm{p}-\mathrm{n}$ heterojunctions and in base layers caused a revolution in solar cell technology based on heterostructures. Really, the creation of SQW and delta - doped layers enhanced reverse SC saturation current reduction $[24,25]$. The MQW insertion in i-layer of $p-i-n$ junction SCs stimulates the efficiency rise as well [26,27]. The latter effect is achieved due to the expansion of photosensitivity spectra and the photocurrent increase $(40 \%)$ as a result of better carrier separation in quantum wells at a constant value of the open circuit voltage (the variation was no more than $0.03 \mathrm{~V}$ ).

As a rule in GaAs SCs the AlGaAs solid solution is used for wide gap windows. AlAs is corrosions unstable material. If $\mathrm{Ga}$ or In atoms are added to the AlAs compound the stability of material is essentially improved. However, a great oxidation velocity still characterizes the AlGaAs solid solutions.

During last ten years a lot of attempts were carried out for replacing of the AlGaAs solid solutions by more stable compounds, for example, InGaP. The heterostructures InGaAs/GaAs, InGaP/GaAs, InGaAsP/ InP and AlGaInP /InGaAs are considered as the most perspective photoelectric materials [35-45]. The most important factor for these material applications is the best radiation stability and lifetime of InP based devices in comparison with AlGaAs based SCs $[46,50,55,56]$.

The typical parameters of InGaP/GaAs SCs and their dependences on temperature and electron radiation are presented in Table 2. As one can see there is a great advantage of these type SCs in comparison with not only $\mathrm{Si}$ SCs, but with GaAs SCs, too [3].

The highest efficiency of InGaP / GaAs SCs is consequence of at least two reasons: i) The wider band gap of InGaP material in comparison with $\mathrm{AlGaAs}$ band gap gives the possibility for expansion of spectral photosensitive range. ii) The AlGaAs / GaAs heterojunction is characterized by the essential conduction band discontinuity, while for InGaP / GaAs heterojunction the larger band discontinuity observed for v-band. As a result, the more mobile photo carriers - electrons - are better separated by the $p-n$ junction electric field [46]. Replacement of homogeneous $\mathrm{p}$ - and n- layers in the $\mathrm{p}-\mathrm{i}-\mathrm{n} \mathrm{InGaP} / \mathrm{InP}$ structure by a super lattice gives the possibility to additionally increase the $U_{\mathrm{oc}}, \mathrm{FF}$ and $\eta$ of such SCs $[35,43]$.

\section{Tandem solar cells}

The efficiency of best GaAs solar cells $(27 \%)$ with accuracy near $10 \%$ is in conformance with the theoretically predicted value $(30 \%)$ for GaAs SCs with single p-n junction [12]. Practically, the unique possibility for improvement of these type devices consists in creation of the tandem (cascade) converters. This possibility is based on more effective usage of solar radiation energy, that has a wide wavelength range (visible, near infrared and infrared). If the solar radiation is decomposed on its spectral components, selecting semiconductor materials with optimum band gap for each spectrum range can produce 
T. V. Torchynska et al.: III-V material solar cells for space application

Table 4. The best world results for the efficiency of tandem solar cells

\begin{tabular}{l|c|l}
\hline \hline Structure & Efficiency & Production firms \\
\hline InGaP /GaAs & $\begin{array}{c}26.9 \% \\
\text { AMO at } 28^{\circ} \mathrm{C}\end{array}$ & $\begin{array}{l}\text { Toyota Technological Inst. } \\
\text { Japan Energy Corporation }\end{array}$ \\
\hline $\mathrm{InGaP} / \mathrm{GaAs} / \mathrm{Ge}$ & $\begin{array}{c}32.3 \% \\
\text { Concentrator solar cell }\end{array}$ & $\begin{array}{l}\text { Spectrolab,USA } \\
\text { Nat.Renewable Energy Lab, USA }\end{array}$ \\
\hline $\mathrm{InGaP} / \mathrm{GaAs} / \mathrm{Ge}$ & $23.0 \%$ & EMCORE \\
\hline $\mathrm{GaAs} / \mathrm{GaSb}$ & $\mathrm{AMO}$ at $28^{\circ} \mathrm{C}$ & \\
\hline $\mathrm{GaInP} / \mathrm{GaInAs}$ & $31.4 \%$ & $\begin{array}{l}\text { Fraunhofer Inst. of Solar } \\
\text { Energy Systems, Germany }\end{array}$ \\
\hline \hline
\end{tabular}

the light conversion into electric energy.

Creation of cascade SCs is one of the main outlook directions for the increase of solar energy photoelectric conversion efficiency. Two main types of cascade SC are known. In the first type of SCs the selective mirrors are used. They split solar radiation into a few spectral components, every one of which is sent to the different SCs. In the second type the SCs are placed one after another with decreasing band gaps along the light beam spreading. The upper wide band gap element of such cascade converts the short wave part of the solar spectrum with minimum losses of photon energy. The lower narrow gap SC allows using of the considerable part of long wave solar radiation. Using a sufficiently high quantity of semiconductor materials, the efficiency of solar energy conversion can approach to $60 \%$. This fact is the basis for creation of cascade solar cells.

Two varieties of the second type of cascade SCs exist: composite and monolithic constructions [28-30]. The latter one is more perspective. Materials with different band gaps and the same crystal structure are needed for creation of monolithic cascade converters. The III-V compounds are the most promising materials, which best of all satisfy above-mentioned conditions. Table 3 presents the efficiency values, predicted by the theory, for cascade converter with two $\mathrm{p}-\mathrm{n}$ junctions and with concentrator of solar radiation [8]. So, for two-element photo converter based on semiconductor materials with band gap $\mathrm{E}_{\mathrm{g}}=1.1 \mathrm{eV}$ and $1.68 \mathrm{eV}$, respectively, the total efficiency is $33 \%$ for solar light concentration coefficient $\mathrm{C}=1$ and $38 \%$ for $\mathrm{C}=200$.

There are a lot of articles connected with the theoretical optimization of two $\mathrm{p}-\mathrm{n}$ junction tandem converter parameters. Paper [31], for example, demonstrates the calculated data for tandem SC with two p-n junctions based on $\mathrm{Al}_{\mathrm{x}} \mathrm{Ga}_{1-\mathrm{x}} \mathrm{As}$ and $\mathrm{In}_{\mathrm{y}} \mathrm{Ga}_{1-\mathrm{y}} \mathrm{As}$ solid solutions with total SC efficiency of $35.0-35.4 \%$.

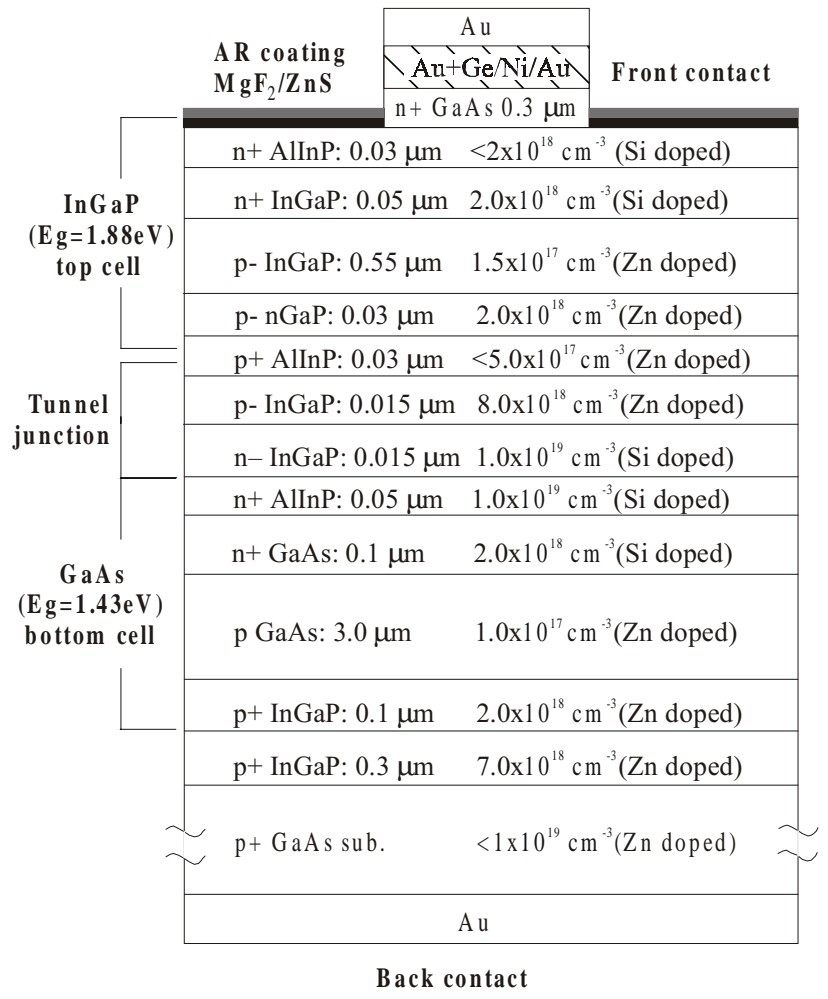

Fig. 3. Cascade two-junction solar cell structure [56].

Table 3. Calculated parameters of two-element cascade converter

\begin{tabular}{|c|c|c|c|c|c|}
\hline $\begin{array}{c}\text { SC } \\
\text { band } \\
\text { gaps }\end{array}$ & \multicolumn{3}{|c|}{$\mathrm{C}=1$} & \multicolumn{2}{c|}{$\mathrm{C}=200$} \\
\hline $\mathrm{E}_{\mathrm{g}, \mathrm{eV}}$ & $\mathrm{I}_{\mathrm{sc}}\left(\mathrm{A} / \mathrm{m}^{2}\right)$ & $\mathrm{U}_{\mathrm{oc}}, \mathrm{V}$ & $\eta, \%$ & $\mathrm{U}_{\mathrm{oc}}, \mathrm{V}$ & $\eta, \%$ \\
\hline 1.1 & 225 & 0.68 & 10.6 & 0.75 & 13.1 \\
\hline 1.68 & 225 & 1.18 & 22.4 & 1.31 & 24.9 \\
\hline
\end{tabular}




\section{T. V. Torchynska et al.: III-V material solar cells for space application}

Known are the attempts for creation of the two-element tandem converter based on AlGaAs and GaAs p-n junctions [12, 32, 33] as well as InGaP and GaAs p-n junctions [50-58]. AlGaAs/GaAs tandem devices have $\eta=25.5 \%$ at $A M 2$ and sun concentration $C=10$. For creation of a efficient tandem SC is very important to solve the task connected with the current flow through the contact between two p-n junctions (Fig. 3). This contact in monolithic tandem SC should provide very efficient carrier tunnel effect [34]. It is evidently that for the achievement of the cascade SC efficiency predicted by theory, the further improvement of the SC technology and design will be needed. Table 4 presents the world record results for tandem solar cell efficiency, which were received in recent two years.

\section{Operation conditions for photovoltaic bat- tery in the space}

Sun radiation, electron and proton particles from Earth radiation belts, vacuum and thermocycling affect on the photovoltaic (PV) battery in space orbits $[2,3,46]$. Radiation protective glasses cover PV batteries as a rule with the aim of radiation influence decrease. The efficiency of glass protection depends on glass thickness. The latter can be changed from 0.1 up to $0.5 \mathrm{~mm}$ for different space orbits.

Application of solar concentrators could be used not only to increase SC output electric power, but also to some degree for radiation protection [9]. But the high level of sun light concentration requires a complicated thermo holder design. Thus, for space application it is reasonable to use sun concentration no more than $\mathrm{C}=10$ 50 .

One of the negative factors acting upon PV battery in the space is radiation electrization. The protective glass covering the PV battery surface can accumulate the electric charges. As a result, at the essential value of this charge, the glass electrical breakdown could be initiated.

But radiation and cycling temperature changes are the most important factors, which affect on PV battery on the space orbits. The calculated dates of radiation expositions for the satellites, worked during 3-5 years on low earth orbits (LEO) with altitude $\mathrm{H}=700-2000 \mathrm{~km}$ or on geosynchronous earth orbits (GEO) with $\mathrm{H}=36000 \mathrm{~km}$, are presented in Table 5. As can be seen, GEO are attractive for commercial reasons, but are extremely challenging for satellite designers because of particle radiation. The main body of satellite can be shielded, but solar cells must be exposed, so superior radiation - hard characteristics will be needed to exploit GEO.

The satellite flying around Earth alternated with coming it in dark or in sun exposed sides of Earth. The latter enhances a thermo cycling variation of PV battery temperatures. For example, the space orbit with $\mathrm{H}=2000 \mathrm{~km}$ is characterized by a temperature variation from $-55^{\circ} \mathrm{C}$ up to $60{ }^{\circ} \mathrm{C}$. On Soviet lunar landing automatic station the temperature fluctuation changes were from $200^{\circ} \mathrm{C}$ up to $200^{\circ} \mathrm{C}$. The strong PV battery temperature fluctuations

SQO, 5(1), 2002
Table 5. Radiation effects on space orbits

\begin{tabular}{lll}
\hline Orbit altitude, $\mathrm{km}$ & $\begin{array}{c}\text { Electron dose, } \\
\text { rad }\end{array}$ & Proton dose, rad \\
\hline $700(98 \mathrm{grad})$ & $3.9 \times 10^{5}(3$ years $)$ & $9 \times 10^{5}(3$ years $)$ \\
\hline $1400(63 \mathrm{grad})$ & $9.6 \times 10^{6}(3$ years $)$ & $1 \times 10^{6}(3$ years $)$ \\
\hline $2000(51 \mathrm{grad})$ & $1.5 \times 10^{7}(3$ years $)$ & $4.3 \times 10^{6}(3$ years $)$ \\
\hline $36000(0$ grad $)$ & $4 \times 10^{8}(5$ years $)$ & $7 \times 10^{6}(5$ years $)$ \\
\hline \hline
\end{tabular}

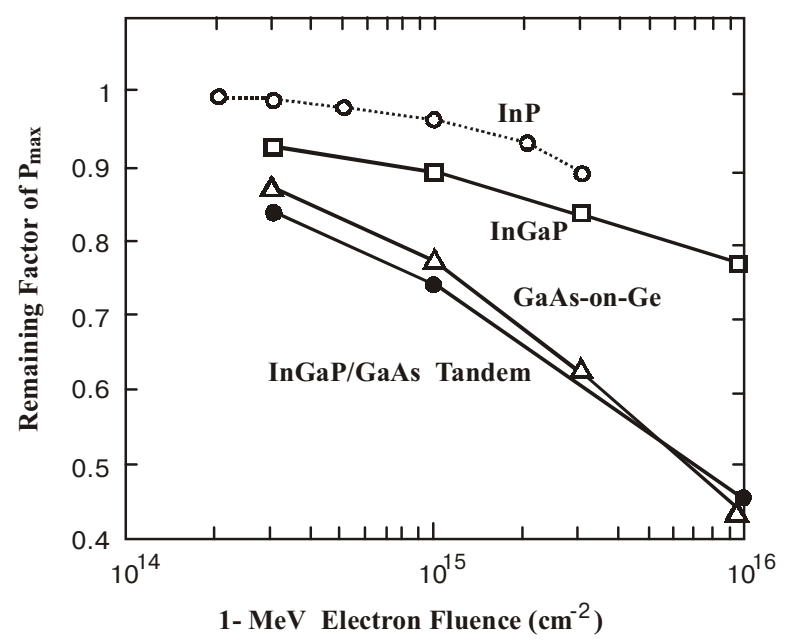

Fig. 4. Solar cell parameter changes with $1 \mathrm{MeVelectron}$ irradiation [56].

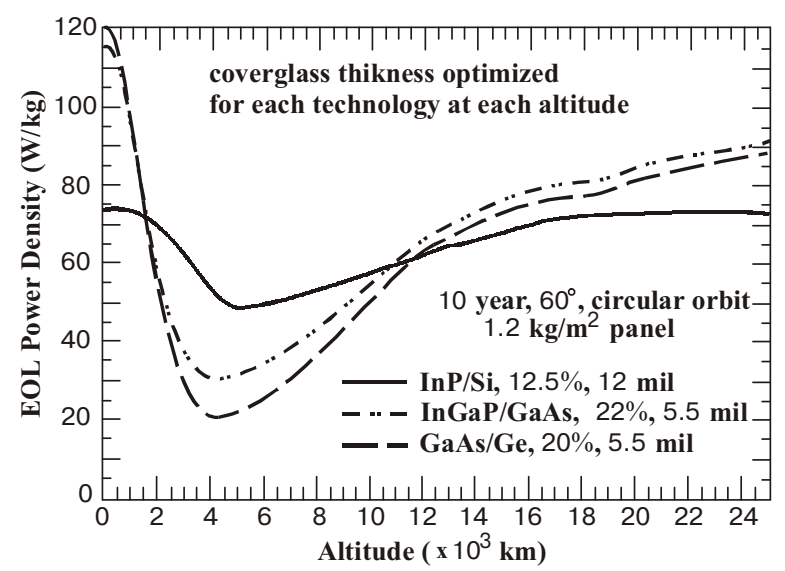

Fig. 5. Calculated end-of-life power density on different space orbits

are extremely challenging for SC thermo-stability parameter.

The studies connected with the researches of radiation impact, high level solar exposition and temperature on SC parameters, as a rule, accompanied by the SC design improvement [4,10-18]. It was shown that $\mathrm{SC}$ radiation degradation essentially depend on the $p-n$ junction depth and the quality of the semiconductor structures [12]. Laboratory test results for variation of output parameters for Si and GaAs and InGaP SCs at electron beam radiation and temperature changes are presented in Table 2 [3]. As can be seen, InGaP based SCs are characterized by the lowest values of efficiency variation with temperature, than $\mathrm{Si}$ and GaAS SCs and better radiation 


\section{T. V. Torchynska et al.: III-V material solar cells for space application}

stability. The latter effect in InGaP based SCs could be explained by the recombination enhanced annihilation of radiative point defects $[4,10]$. Both of these aspects give the chance to expect the low degradation velocity of InGaP SCs parameters and longer lifetime (up to 15 years) on space orbits.

The comparative analysis of the radiation response for InP / Si, InGaP and tandem InGaP / GaAs space SCs at both electron and proton irradiation is presented in $[50,55,56]$. The parameters of the radiation degradation are used for prediction of end-of-life (EOL) performances of solar panels on Earth orbit (Fig. 4). It has been shown, that tandem InGaP/GaAs SCs in orbits outside the earth radiation belts $(\mathrm{H}<2000 \mathrm{~km})$ provide the highest EOL specific power. However, in orbits which pass through the radiation belts $(2000 \mathrm{~km}<\mathrm{H}<20,000 \mathrm{~km})$, where the radiation is hard, the $\mathrm{InP} / \mathrm{Si} \mathrm{SCs}$ provide the highest power on more than $30 \%$ (Fig. 5).

\section{The current international space projects}

III-V material solar cell advantages mentioned above were completely confirmed at the GaAs solar battery operation in Soviet "Lunokhod-1, -2" and American "Apollo-14, -15" automated stations in lunar surface missions. GaAs solar batteries at $\mathrm{T}=130-140{ }^{\circ} \mathrm{C}$ on the lunar surface generated an electrical power more than 2 times bigger than power calculated for the Si battery in those conditions.

Starting from 1980 GaAs solar battery are actively flight tested and in 1990 begun to be board used in commercial satellites: ESA: UOSAT (January 1990), TUBSAT (June 1991), STRV-1A (June1994), UPM/LB Sat (February 1995). ASI: ASGA on EURECA (July 1992). ASI-CNES COOPERATION: ARSENE (May 1993). ASI-CONAE-NASA COOPERATION: SAC-B (1996). Commercial minisatellites: OERSTED (1997), MINISAT (1996), UNAMSAT (1996), SUPERBIRDS1-4 (1998-2000).

The most famous evidence of the switching of space energy production interest from Si to III-V material SCs is the current space projects [3]. Telecommunication satellites, as a rule, are intended for a geosynchronous orbit, where it can arrange connection with 1/3 of the Earth's surface. But as can be seen from Table 5, GEO is characterized by a high particle radiation and, therefore, hard operation regimes.

The current space projects are directed to the development of new class of telecommunication systems, the so-called "satellite network". The latter is a chain of interlinked satellites, which are put into low Earth orbits (LEO). The satellite into the LEO covers the smaller earth's surface, but the time required to transmit data is also reduced. The latter is positive factor for broadband communications, although more satellites are necessary in that case. It is also essential that for LEO the influence of a particle radiation on the satellite is reduced and its operation time rises. Table 6 demonstrates an example of satellite telecommunication projects, which are just now developed or proposed [3]. Experts estimate that nearly $50-70 \%$ of all commercial satellites now under construction will be equipped with III-V material solar cells. The forecast for the satellite business looks rather good, with plans for several dozen units a year for the next several years [3]. Thus, we are the witnesses now of the revolution in the semiconductor space solar cell engineering development.

Table. 6. Proposed space systems

\begin{tabular}{|l|l|c|c|}
\hline \hline System & Proponents & Satellites & Orbit Altitude $(\mathrm{km})$ \\
\hline Spaceway & Hughes & 8 & 35.000 \\
\hline Odyssey & TRW & 12 & 10.350 \\
\hline Immarsat P & Immarsat & 10 & 10.350 \\
\hline Globalstar & Loral/Qualcomm & 48 & 1.390 \\
\hline Iridium & Motorola & 66 & 740 \\
\hline Teledesic & McCaw Cellular & 840 & 700 \\
\hline
\end{tabular}

\section{Conclusions}

The advantages of III-V material SCs in comparison with that of Si listed below making these SCs more attractive for space applications:

- output power per square unit on $30 \%$ more at the same sun light exposition;

- radiation reliability is over $20 \%$ higher for the same operation conditions;

- coefficient of efficiency change with temperature in 2 times smaller;

- lifetime on orbits on $40-60 \%$ more;

- the efficiency of energy conversion more than on 20 $25 \%$ high.

\section{References}

1. 1. D.Coiante, L.Barra, Can photovoltaic become an effective energy option, Solar Energy Materials and Solar Cells, 1992, v.27, pp.79-89

2. V.A.Grilikhes, Space solar energy station, Leningrad, "Nauka", 1986.

3. M.Meyer, R.A.Metzger, Flying High: The commercial Satellite Industry Converts to Compound Semiconductor Solar Cells, Compound Semiconductor, 1997, Special Issue, pp.4042.

4. A.L.Fahrenbruch, R.H.Bube, Fundamentals of solar cells. Photovoltaic solar energy conversion, N.-Y., Academic Press, 1983.

5. J.J.Lion, W.W.Wong, Comparison and optimization of the performance of $\mathrm{Si}$ and GaAs solar cells, Sol. Energy Materials and Solar Cells, 1992, v.28, pp.9-28.

6. M.Tsugami, K.Mitsui, "GaAs solar cells by MOCVD", Optoelectronics, Devices and Technologies, 1989, v.4, n.1, pp.59-66. 


\section{T. V. Torchynska et al.: III-V material solar cells for space application}

7. J.J.Liou "Physical models for predicting the performance of $\mathrm{Si} / \mathrm{Si}, \mathrm{AlGaAs} / \mathrm{GaAs}$ and $\mathrm{Si} / \mathrm{SiGe}$ solar cells, Solar Energy Materials and Solar Cells, 1993, v.29, p.261-276.

8. Current Topic in Photovoltaics, Edit.T.J.Coutts, J.D.Meakin, NY. Academic Press, 1985, pp.194-198.

9. A.A.Alaev, B.M.Andreev, "Radiation defect annealing in $\mathrm{AlGaAs} / \mathrm{GaAs}$ hetero-photoelements at working with sun concentrator, "Heliotechnics", n.5, p.32-35.

10. V.M.Andreev, V.S.Kalinovskiy, V.R.Larionov, E.O.Strugova,V.D.Rumyanzev, " Characteristics of AlGaAs/ GaAs photodiodes on low energy ionization radiation" Fiz. Tekh. Polupr., 1994, v.28, n.2, pp.338-341.

11. V.M.Andreev, G.M.Gusinskiy, "Radiation influence on $\mathrm{AlGaAs} /(\mathrm{p}-\mathrm{n}) \mathrm{GaAs}$ heterostructure photoelectric parameters, Fiz. Tekh. Polup., 1988, v.22, n.8, p.1391-1395.

12. V.M.Andreev, V.A.Grikhiles, V.D.Rumyanzev, Photoelectric conversion of sun concentrated radiation, Leningrad, "Nauka", 1989, 320p.

13. G.M.Grigoreva, V.A.Grikhiles, "Radiation effects in heterostructure AlGaAs / GaAs photoelements on high exposition and temperature","Heliotekhnica", 1989, n.1, p.8-12.

14. V.M.Andreeva, G.M.Grigoreva, Dependence of p-AlGaAsp - GaAs-п- GaAs heterostructure degradation on recombination precesses, "Heliotekhnica", 1988, n.2, p.84-85.

15. V.M.Botnaryuk, L.V.Gorchak, Photoelectric parameter degradation in hetero photo converters under electron radiation, "Heliotekhnica", 1990, n.1, p.6-7.

16. M.Ya.Bakirov, A.Berkeliev, Radiation effects in AlGaAs / GaAs hetero photo converters at joint radiation and load affects, "Heliotekhnica", 1990, n.6, p.47-49.

17. V.M.Andreev, T.M.Golovner, Photoelectric characteristics of high efficient AlGaAs / GaAs solar converters, Fiz. Tekh. Polup., 1978, v.7., n.12., p.2289-2296.

18. V.I.Polyakov, P.I.Perov, "Photosensitivity spectra of AlGaAsGaAs- GaAs heterostructure, Fiz. Tekh. Polup , 1986. v.20,n.9, p.1605 -1609

19. Zh.I.Alferov, V.M.Andreev, Photoelectric characteristics of AlGaAs - GaAs heterostructure, Fiz. Tekh. Polup , 1978.v.12, 2, p. 285-292.

20. Zh.I.Alferov, V.M.Andreev, Photoelements based on $\mathrm{AlGaAs}$ heterostructures with transition layer, Pisma Zhurn. Tekhn. Fiz., 1978, v.4, n.6., p.305-307.

21. V.M.Andreev, B.V.Egorov, Heterophotoelements with low reverse saturation current, Fiz. Tekh. Polup , 1985. v.19, n.2, p.276-281.

22. Solar energy conversion, Ed. B.O.Seraphin, Springer-Verlag, Berlin, Heidelberg, N-Y. 1979.

23. A.Iskanderov, Kh.Kh. Bustanov, Photosensitive structures and solar elements based on GaAs, Tashkent, "FAN", 1986, p.144-148.

24. R.W.Boer, J.Piprek "Inverse Delta-Doping for Improvement of Solar Cells", Proceedings of the $12^{\text {th }}$ European Photovoltaic Solar Energy Conference and Exhibition, Amsterdam,1994.

25. Y.Qiang, E.Look "Photoreflectance Study of GaAs and GaAs/AlGaAs Single Quantum Wells Grown on (001) Si Substrates, Solar Energy Materials and Solar Cells, 1994, v.32, pp.405-411.

26. F.W.Ragay, J.H.Wolter, "Experimental analysis of the efficiency of MQW solar cells" Proceedings of the $12^{\text {th }}$ European Photovoltaic Solar Energy Conference and Exhibition, Amsterdam, 1994

27. J.J.Barnes, T.Ali "Gallium Arsenide/ Indium Gallium Arsenide Multi Quantum Well Solar Cells, Proceedings of the $12^{\text {th }}$ European Photovoltaic Solar Energy Conference and Exhibition, Amsterdam, 1994

28. F.A.Akhmetov, Three cascade photoconverter based on GaAs - AlGaAs heterostructures, "Heliotekhnic", 1994, n.2, p.15-17.

29. M.A.Abdukadyrov, Cascade solar elements with two side sensitivity based on GaAs - AlGaAs double heterostructures and silicon, "Heliotekhnic", 1991, n.2, p.38-39.

30. A.M.Alakhverdiev, V.M.Andreev, Cascade Si-AlGaAs solar photoelements, Fiz. Tekh.Polupr., 1984, v.18, n.1, p.121124.

31. M.F.Lamorte, D.Abbott, "Analysis of AlGaAs-GaInAs cascade solar cell under AM0-AM5 spectra", Solid State Electronics, 1979, v.22, pp.467-473.

32. Zh.I.Alferov, V.M.Andreev, Investigation of cascade solar cells in Al-Ga-As systems, Fiz. Tekh. Polup., v.16., n.6, p.982986.

33. A.M.Alakhverdiev, Yu.M.Zadiranov, Joint influence wide and narrow band photoelements at cascade n-GaAs-pAlGaAs-n-AlGaAs element work, Fiz. Tekh. Polupr., 1983, v.17., n.3., p.446-448.

34. A.Taylor, B.Beamount, and J.C,Guillaume,'Improved Efficiency in $\mathrm{Ga}_{0,47} \operatorname{In}_{0,53}$ As Tunnel Diodes for the Monolithic Tandem InP/ $\mathrm{Ga}_{0,47} \mathrm{In}_{0,53}$ As Grown by OMVPE” Proc. of the $12^{\text {th }}$ EC Photovoltaic Solar Energy Conference, Amsterdam, 1994

35. A.C.Varonides, New Heteroepitaxial InP/InGaAs novel n(superlattice) - i - p(superlattice) Solar Cell for Space Applications. Proc. of the $12^{\text {th }}$ EC Photovoltaic Solar Energy Conference, Amsterdam, 1994.

36. A.van Geelen, R.A.J.Thomeer, AlGaInP windows for $\mathrm{p}$ on $\mathrm{n}$ $\mathrm{Ga}_{0,5} \mathrm{In}_{0,5} \mathrm{P}$ solar cells, Proc. of the $12^{\text {th }}$ EC Photovoltaic Solar Energy Conference, Amsterdam, 1994.

37. V.M.Andreev, L.B.Karlina "Narrow gap InGaAs/InP solar cells illuminated through transparent InP substrate" Proc. of the $12^{\text {th }}$ EC Photovoltaic Solar Energy Conference, Amsterdam, 1994.

38. Sulima, O.V. 1; Bett, A.W.; Dimroth, F.; Keser, S.; Stollwerck, G.; Wettling, W., III/V-materials for tandem concentrator solar cell application“, Proc. International Symposium on Compound Semiconductors ISCS-23, St. Petersburg, Russia, 1996, p. 23.-27.9.

39. Wettling, W.; Mertens, R.P.1; Sinke; W.C.2; Schock, H.W.3"Photovoltaic cells - an overview", Proc. EuroSun 96,Freiburg, 1996, 16.9.-19.9.

40. Granqvist, C.G. 1; Wittwer, V. "Materials for solar energy conversion: an overview“, Proc. of EuroSun 196, Freiburg, 16.9.-19.9.1996.

41. Bett, A.W.; Dimroth, F.; Keser, S.; Stollwerck, G.; Sulima, O.V.; 36.

42. Wettling, W. "A concept for $30 \%$ efficiency: Tandem-Concentrator Solar Cells", Proceedings EuroSun r96, Freiburg, 1996, 16.9.-19.9.

43. Yang, M.-J., Yamaguchi, M., Takamoto, T., Ikeda, E., Kurita, H., Ohmori, M. Photoluminescence analysis of InGaP top cells for high-efficiency multi-junction solar cells, 1997, v.45, p. 331-339.

44. Shigeru KURODA and Masahiko TAKIKAWA Electron devices using InGaP/GaAs heterojunction, OYO BUTURI, 1996, v.65, No.2, pp.132-137.

45. R. Platz, J. Meier, D. Fischer, S. Dubail, A. Shah, «The Problem of the Top Cell for the Micromorph Tandem», in Proceedings of the MRS Symp., SanFrancisco, April 1997.

46. T.V.Torchinskaya, Current status of space and terrestrial solar energetics, Int. J, Opto-Electronics , 1998, v.6(2), pp.121130, (Review).

47. Fischer, H. Keppner, U. Kroll, P. Torres, J. Meier, R. Platz, S.»Recent Progress of the «Micromorph» TANDEM Solar Cells», in Proc. of the 14th EC Photovoltaic Solar Energy Conference, Barcelona, July 1997.

48. A.Yamamoto, M.Tsujino, M.Ohkubo, A.Hashimoto, "MOCVD growth of InN for InN/Si tandem solar cells, Solar Energy Materials and Solar Cells, 1994, v.35, pp.53-57.

49. J.R.Bates, P.H.Fang "Results of solar cell performance on lunar base derived from Apollo missions" Solar Energy Materials and Solar Cell, 1992, v.26, pp.79-84

50. M.Yamaguchi, T.Okuda, S.J.Taylor, T.Takamoto, Superior radiation-resistant properties of $\mathrm{InGaP} / \mathrm{GaAs}$ tandem solar 


\section{T. V. Torchynska et al.: III-V material solar cells for space application}

cells, Appl.Phys.Lett, v.79, 1997, p.1566-1568.

51. J.M.Olson, S.R.Kurtz, A.E.Kibbler, P.Faine, A $27,3 \%$ efficient $\mathrm{Ga}_{0,5} \mathrm{In}_{0,5} \mathrm{P} / \mathrm{GaAs}$ tandem solar cell, Appl.Phys.Lett., v.56(7), 1990, pp.623-625.

52. K.A.Bertness, S. R. Kurtz, D.J.Friedman, A.E.Kibbler, C.Kramer, J.M.Olson, 29.5\% efficient GaInP / GaAs tandem solar cells, Appl.Phys.Lett., v.65(8), 1994, pp.989-991.

53. M.Yamaguchi, T.Okuda, S.J.Taylor, Minority-carrier injection-enhanced annealing of radiation damage in InGaP solar cells, Appl.Phys.Lett, v.70, 1997, pp.2180-2182.

54. T.Takamoto, E.Ikeda, H.Kurita, Over $30 \%$ efficient InGaP/ GaAs tandem solar cells, Appl.Phys.Lett., v.70, 1997, pp.381383.

55. R.J.Walters, H.L.Cotal, S.R.Messenger, E.A.Burke, S.J.Woitczuk, H.B.Serreze, P.R.Sharps, M.L.Timmons, P.Iles, J.C.M.Yeh, "Radiation response of InP\&Si and InGaP\&GaA space solar cells", Solar Energy Materials\&Solar Cells, v.50 (1998), pp.305-313.
56. T.Takamoto, M.Yamaguchi, S.J.Taylor, Ming-Ju Yang, E.Ikeda, H.Kurita, Radiation resistance of high-efficiency InGaP/GaAs tandem solar cells, Solar Energy Materials \& Solar Cells v.58, 1999, pp.265-276.

57. R.A.Kumar, M.S.Suresh, J.Nagaraju, Measurement and comparison of AC parameters of silicon (BSR and BSFR) and gallium arsenide $(\mathrm{GaAs} / \mathrm{Ge})$ solar cells used in space applications, Solar Energy Materials \& Solar Cells, v.60, 2000, pp.155-166.

58. N.H.Karam, R.R.King, M.Haddad, J.H.Ermer, H.Yoon, H.L.Cotal, R.Sudharsanan, J.W.Eldredge, K.Edmondson, D.E.Joslin, D.D.Krut, Recent development in high-efficiency $\mathrm{Ga}_{0.5} \mathrm{In}_{0.5} \mathrm{P} / \mathrm{GaAs} / \mathrm{Ge}$ dual- and triple-junction solar cells: steps to next-generation PV cells, Solar Energy Materials \& Solar Cells, v.66, 2001, pp.453-466. 